\title{
An Empirical Study on Effecting Characteristics of Financial Services on Use Intention: Focusing on Asset Management of Mobile FinTech Using Alipay
}

\author{
Lin-Lin Zhang ${ }^{1}$ and Ha-Kyun Kim ${ }^{2}$ \\ ${ }^{1}$ Doctoral Student of Graduate School of Information Systems, Pukyong National \\ Univ. 45, Yongso-ro, Nam-Gu, Busan, Korea \\ ${ }^{2}$ Professor (Corresponding Author) of Division of Business, Pukyong National Univ. \\ 45, Yongso-ro, Nam-Gu. Busan, Korea \\ 123126501@hanmail.net, ${ }^{2}$ kimhk@pknu.ac.kr
}

\begin{abstract}
After reviewing previous studies on financial service characteristics, customer satisfaction and usage intentions, an empirical study was conducted. Financial services are characterized by convenience, profitability, security and flexibility. The study aims to analyze what factors influence the intent of users based on FinTech-based Alipay to manage personal assets. This article uses SPSS 22.0 as the basic statistics and uses the structural equations to analyze Smart PLS 2.0 (partial least squares). The findings are as follows. First, the characteristics of financial services (convenience, benefit, security, and flexibility) have a major impact on customer satisfaction. Second, customer satisfaction has a significant impact on usage intentions.
\end{abstract}

Keywords: Convenience, Benefit, Security, Flexibility, Customer satisfaction

\section{Introduction}

The term FinTech was first introduced in a paper by Bettingers [1]. FinTech collectively refers to new financial services that combine "finance" and "technology". New financial technologies utilizing smart technologies, especially mobile, are promoting the efficiency of existing financial systems and promoting ICT convergence of financial services [2].

The application of new technologies will enable the financial industry to serve niche markets and promote change and development into universal, microfinance and wisdom financing. Recently, China's financial services industry has been transformed into "intelligent finance" in the 3.0 era. The efficiency and quality of financial services continue to increase. According to the recent five-year China Internet Development Statistics Report, Internet wealth management users continue to grow from 78.49 million in 2014 to 1.5 billion in 2018 .

AliPay was used as a third-party secure payment tool in the early stages of e-commerce in China, but has now grown into a lifestyle living service platform. The hotel offers a variety of services, including hotel reservations, movie ticket purchases, utility bill payments, online hospital receptions or asset management products.

Article history:

Received (March 6, 2019), Review Result (July 9, 2019), Accepted (October 12, 2019) 
Introducing "flexibility" as an important factor to consider in the financial services characteristics of mobile asset management. This is a preliminary variable to grasp the customer's use intention, and helps to identify the customer's satisfaction.

The purpose of this study is to examine the characteristics of financial services of asset management through Alipay for Chinese people, and to examine how it affects customer satisfaction and how customer satisfaction affects intention of use through empirical analysis.

\section{Theoretical background}

\subsection{Characteristics of mobile financial services}

Mobile finance is a combination of "wireless," "online" and "finance." It means a combination of wireless features available anywhere, the features of online services available at any time, and features of existing and new financial services [3].

\subsection{Customer satisfaction}

User satisfaction is the state of mind that users perceive after using FinTech services to the extent that they believe the effects of mobile use meet their expectations [4].

\subsection{Use Intention}

Use Intention is a psychological decision that an innovation or service makes when it feels convenient, easy to use, and useful [5].

\section{Research design}

\subsection{Research model}

According to the research on the characteristics of mobile financial technology financial services, they are considered to have a significant impact on the customer's intention to use. Therefore, the characteristics, convenience, benefits, security and flexibility of mobile financial technology financial services were chosen as variables. A research model was designed based on previous studies, as shown in [Figure.1].

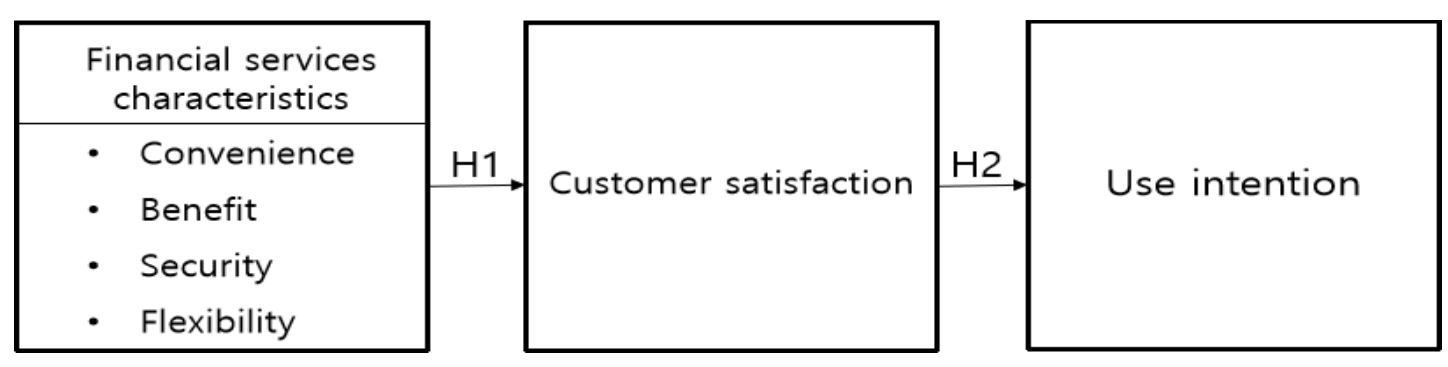

Figure 1. Research model turnover

\subsection{Research hypothesis}

\subsubsection{Hypothesis on financial service characteristics and customer satisfaction}

This study defines the characteristics of mobile financial services as convenience, benefit, security, and flexibility based on previous studies. 
Hypothesis H1: Financial services characteristics have a significant impact on customer satisfaction responses.

Hypothesis H1-1: Convenience among financial service characteristics has a positive effect on customer satisfaction.

Hypothesis H1-2: Benefits among financial service characteristics have a positive effect on customer satisfaction.

Hypothesis H1-3: Security among the characteristics of financial services has a positive effect on customer satisfaction.

Hypothesis H1-4: Flexibility among the characteristics of financial services has a positive effect on customer satisfaction.

\subsubsection{Hypothesis on customer satisfaction and use intention}

In previous studies on the use intention mobile banking, user satisfaction showed a positive effect on acceptance intention [6][7].

Hypothesis H2: Customer satisfaction has a positive effect on use intention.

\subsection{Empirical analysis and results}

\subsubsection{Analysis method of data}

For the analysis of the survey, the structural model used Smart PLS 2.0. Concentration validity checks factor loading, compositional reliability (C.R.) and variance extraction index (AVE) of each factor. In general, factor loading value is 0.6 or more, configuration reliability value is 0.7 or more and variance extraction index value is 0.5 or more to be.

The discriminant validity has no problem in discriminant validity since the square root value of the variance extraction index is compared with the correlation coefficient.

Table 1. Reliability and internal consistency

\begin{tabular}{|c|c|c|c|c|}
\hline Variables & Factor Loading & AVE & C. R. & Cronbach's $\alpha$ \\
\hline \multirow{2}{*}{ Convenience } & 0.881 & \multirow{2}{*}{0.822} & \multirow{2}{*}{0.902} & \multirow{2}{*}{0.788} \\
\hline & 0.932 & & & \\
\hline \multirow{2}{*}{ Benefit } & 0.880 & \multirow{2}{*}{0.770} & \multirow{2}{*}{0.870} & \multirow{2}{*}{0.702} \\
\hline & 0.875 & & & \\
\hline \multirow{2}{*}{ Security } & 0.917 & \multirow{2}{*}{0.857} & \multirow{2}{*}{0.923} & \multirow{2}{*}{0.833} \\
\hline & 0.934 & & & \\
\hline \multirow{2}{*}{ Flexibility } & 0.931 & \multirow{2}{*}{0.861} & \multirow{2}{*}{0.925} & \multirow{2}{*}{0.838} \\
\hline & 0.924 & & & \\
\hline \multirow{2}{*}{$\begin{array}{l}\text { Customer } \\
\text { satisfaction }\end{array}$} & 0.881 & \multirow{2}{*}{0.773} & \multirow{2}{*}{0.872} & \multirow{2}{*}{0.707} \\
\hline & 0.878 & & & \\
\hline \multirow{2}{*}{ Use intention } & 0.917 & \multirow{2}{*}{0.822} & \multirow{2}{*}{0.903} & \multirow{2}{*}{0.784} \\
\hline & 0.897 & & & \\
\hline
\end{tabular}

Table 2. Correlation and discriminant validity

\begin{tabular}{|c|c|c|c|c|c|c|c|}
\hline Variables & AVE & 1 & 2 & 3 & 4 & 5 & 6 \\
\hline Convenience & 0.822 & 0.907 & & & & & \\
\hline Benefit & 0.770 & 0.523 & 0.878 & & & & \\
\hline
\end{tabular}




\begin{tabular}{|c|c|c|c|c|c|c|c|}
\hline Security & 0.857 & 0.509 & 0.594 & 0.926 & & & \\
\hline Flexibility & 0.861 & 0.458 & 0.659 & 0.629 & 0.928 & & \\
\hline Customer satisfaction & 0.773 & 0.641 & 0.735 & 0.715 & 0.735 & 0.879 & \\
\hline Use intention & 0.822 & 0.465 & 0.654 & 0.726 & 0.729 & 0.745 & 0.907 \\
\hline
\end{tabular}

\subsubsection{Verification of research model}

For the structural model, Smart PLS 2.0 was used. Through the structural model, the path coefficient and the coefficient of determination $\left(\mathrm{R}^{2}\right)$ between the variables of the research model were derived. The coefficient of determination $\left(\mathrm{R}^{2}\right)$ for Customer satisfaction $(0.744)$ and Use intention (0.555) was 'high'.

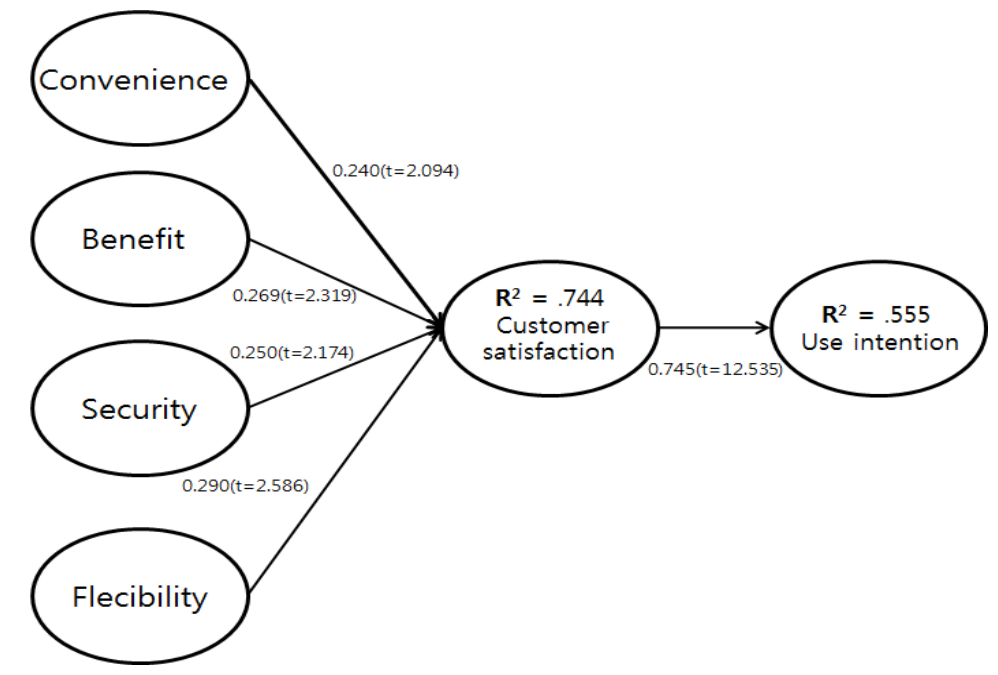

Figure 2. The results of research model

Hypothesis H1-1, "Characteristics of financial services, convenience will have a positive (+) effect on customer satisfaction", "The hypothesis of H1-1 is statistically significant at $97.5 \%$ of significance level $(\mathrm{H} 1-1 ; \beta=0.240, \mathrm{t}=2.094, \mathrm{p}<0.05)$ in relation to each other.

In hypothesis $\mathrm{H} 1-2$, benefit was found to have a significant effect on customer satisfaction $(\beta=0.269, \mathrm{t}=2.319, \mathrm{p}<0.05)$. Among the factors of financial services characteristics affecting customer satisfaction, benefit is significant.

Hypothesis H1-3's security among financial service characteristics has a significant effect on customer satisfaction $(\beta=0.250, t=2.174, p<0.05)$. Among the factors of financial services characteristics affecting customer satisfaction, security is significant.

Hypothesis H1-4's flexibility has a significant effect on customer satisfaction $(\beta=0.290, \mathrm{t}$ $=2.586, \mathrm{p}<0.05$ ). Among the factors of financial services characteristics affecting customer satisfaction, flexibility is significant.

Hypothesis $\mathrm{H} 2$ the hypothesis that "the satisfaction of the customer who manages assets has a positive effect on the intention to use" is significant $(\mathrm{H} 2 ; \beta=0.745, \mathrm{t}=12.535, \mathrm{p}<0.05)$, the hypothesis $\mathrm{H} 2$ was adopted. Customer satisfaction is significant on use intention.

\section{Conclusion}


With the development of the world's ICT technology, China's FinTech industry also grew rapidly. Alipay has grown from a third-party secure payment tool to a lifestyle living service platform. Through Alipay, people not only pay, make hotel reservations, buy movie tickets, pay bills, receive online hospitals, but also manage their assets. In particular, Yu'ebao, an asset management product, attracted the attention of many people at the same time. Therefore, this study carried out empirical analysis on how the characteristics of FinTech financial services affect the intentions of people who use Alipay asset management products[8].

The results of the study are as follows. Hypothesis 1 on the characteristics of financial services and customer satisfaction was adopted. In other words, convenience, benefits, security, and flexibility among financial service characteristics influenced customer satisfaction. Hypothesis 2 about customer satisfaction and customer intention was adopted. In other words, customer satisfaction has a positive effect on customer intention

The results of the study are as follows. Hypothesis 1 on the characteristics of financial services and customer satisfaction was adopted. In other words, convenience, benefits, security, and flexibility among financial service characteristics influenced customer satisfaction. Hypothesis 2 about customer satisfaction and customer intention was adopted. In other words, customer satisfaction has a positive effect on customer intention.

Based on the results of this study, the following implications can be suggested.

First, flexibility was found to have the greatest impact on customer satisfaction. To be competitive, financial companies need to increase the flexibility of their products and services, including flexible subscriptions to diverse customers, flexible withdrawals and subscriptions, and flexible use of funds.

Second, convenience, benefits and security also have a big impact on customer satisfaction. To be competitive, asset management products need to be developed more easily than traditional asset management methods, require customers to benefit more, and design privacy more securely.

Third, the most important thing is to secure customer satisfaction. It was found in this study that customer satisfaction has a great influence on customer's use intention. Therefore, it is most important for financial companies to design the customer's satisfaction with the developed financial products.

\section{References}

[1] Bokseong-su, "4th industrial revolution and big data, information and communication engineering", Chungbuk National University, (2016)

[2] Elizabeth E. and Michael P., "Electronic commerce adoption: an empirical study of small and medium US businesses", Information and Management, vol.42, no.1, (2004) DOI: 10.1016/j.im.2003.12.010

[3] Kazumasa Oguro, "Big data-key to the 4th industrial revolution, innovation in the global economy-3," Japan spotlight, (2016)

[4] McAfee T. and Brynjofsson "Big data: the management revolution," Havard Business Review, October, Davenport, (2006)

[5] Quinn J.B., and Bailey M.N. "Information technology: Increasing productivity in services," Academy of Management Executive, vol.8, no.3, (1994) DOI: 10.5465/ame.1994.9503101167

[6] "Real estate in the age of the fourth industrial revolution", BEOS Survey 05, January, (2014).

[7] Samsung Economic Research Institute, Public data openness and corporate activities, (2013)

[8] Gavin Tay, Carol Rozwell, and DeanFreeman, Gartner, "Use the Internet of Things in Smart Buildings to Achieve Work-Life Ambience," May, (2017) 
An Empirical Study on Effecting Characteristics of Financial Services on Use Intention: Focusing on Asset Management of Mobile FinTech Using Alipay

This page is empty by intention. 